\title{
A NEW \\ HORSESHOE BAT FROM WEST AFRICA
}

BY

\author{
Glover M. ALLEN.
}

In continuation of his previous work in the Cameroons, the Rev. George Schwab has lately forwarded to the Museum of Comparative Zoölogy at Cambridge a small series of bats in alcohol from Sakbayeme, an inland station on the North-Eastern part of the Congo basin.

The collection includes three species of Horseshoe Bats : Hipposideros beatus And., H. fuliginosus (Темм.), and a third which appears to be hitherto undescribed. The first of these, as well as numbers of $H$. caffer guineensis, Mr. Schwab had already obtained at Metet and Ebolowa to the North-West. The small series of $\mathrm{H}$. fuliginosus is of interest in connection with $D^{r}$ Andersen's statement in Igo6 that he then knew of but two authentic examples : the type in the Leiden Museum, and a second specimen in the British Museum.

The new species does not seem closely related to any of the African members of the genus yet known. It may be named : 
HIPPOSIDEROS CURTUS sp. nov.

Trpe. - A female in alcohol, I9305, Museum of Comparative Zoölogy, from Sakbayeme, Cameroons. Rev. George Schwab, collector, I920.

Description. - A small species, about the size of $H$. beatus; female without the frontal glandular sac; tail very short, barely exceeding the exte ded femur; wings from the distal end of tibia; calcar short, about ne half the length of tibia; thumb markedly small and weak as co trasted with $H$. beatus and $H$. caffer guineensis; forearm about : in the latter but wings shorter, the combined length of metacarpal III and its proximal phalanx exceeding the forearm measurement by only I $\mathrm{mm}$. as against $6 \mathrm{~mm}$. in the two other species; metacarpals III and V subequal, IV a trifle longer, whereas in the two contrasted species metacarpals III and IV are about equal, the fifth shorter. Ears, noticeably larger than in either $H$. beatus or H. caffer guineensis; tibia longer than in the former but shorter than in the latter.

The noseleaf is essentially similar in $H$. beatus and H. caffer, but in the new species is of a very different appearance. The horseshoe is noticeably broader and thicker, with a slight median emargination anteriorly, the edges of which are a trifle upturned; the small cushion-like expansion of the nasal septum, nearly obsolete in the two other species, is here considerably developed, and, with the small projections at the outer border of the nasal openings, forms a partial roof over the nares.

The erect «sella " is slightly thickened, densely covered with short stiff hairs, more as in $H$. beatus rather than nearly naked as in H. caffer. The posterior crescent is simple and evenly convex in outline, and is divided by three vertical ridges on its anterior face. There are two lateral accessory leaflets at each side of the horseshoe, but these are very small and poorly developed, 
the outer one a mere wart and so concealed by the hair of the lip that is not easily made out; the larger supplementary leaf is only about half the lateral extent of the horseshoe, instead of nearly as long, as in $H$. caffer and $H$. beatus.

The color is not definable from the alcoholic specimen, but seems to be a uniform dark smoky brown.

Skull shows no striking peculiarities. Contrasted with that of the other two species mentioned, it more resembles that of $H$. caffer guineensie in that the width across $m^{3}$ about equals rather than exceeds the length of the maxillary tooth row; it differs from both in having more terete upper incisors, their outer sloping border without indication of the notch obviously present in the two other species; $p^{3}$ is in contact with canine and $p^{4}$, very small but barely external to the median axis of the tooth row; upper canine with a minute posterior basal cusp; lower canine very slender, nearly equalled in height by $p_{4}$; sagittal crest weakly developed, extending to the back of the parietals; nasal inflation prominent.

Measurements. - Length (circa) $67 \mathrm{~mm}$., tail from anus $\mathrm{I} 7$, tibia 20 , with the foot 27 , ear from meatus 17,5 , width of ear 15 , calcar 10.5 , forearm 47 , third metacarpal 32,5 , with proximal phalanx 48 , fourth metacarpal 35 , with proximal phalanx 45,5 , fifth metacarpal 33 , with proximal phalanx 45 , greatest width of horseshoe 6,5 , of posterior crescent 7,5 .

Skull : total length $17,5 \mathrm{~mm}$., zygomatic breadth 9 , width ontside $m^{3}, 5,8$, upper maxillary teeth 5,7 , lower tooth row $i_{\mathrm{I}}$ to $m_{3}, 6,8$.

Remarks. - Externally this small species is at once distinguishable from $H$. beatus and $A$. caffer guineensis, of similar size and inhabiting the same region, by its very short tail which barely exceeds the extended femur, by its much larger ears, by the short calcar combined with the long slender leg, and by the shorter fingers in comparison with the forearm. The noseleaf is very different, with its broad horseshoe, emarginate anteriorly, reduced 
supplementary lappets, expanded internarial septum, and hairy sella. These characters will also serve to distinguish it from H. nanus, of the Belgian Congo, apparently a close ally of $H$. beatus. For additional notes on the type of $H$. nanus, as well as for carefully executed drawings of its noseleaf, thanks arc due $\mathrm{M}^{r}$ Herbert Lang of the American Museum of Natural History. 


\section{$2 \mathrm{BHL}$ Biodiversity Heritage Library}

Allen, Glover M. 1921. "A new horseshoe bat from West Africa." Revue zoologique africaine 9, 193-196. https://doi.org/10.5962/bhl.part.24480.

View This Item Online: https://www.biodiversitylibrary.org/item/42138

DOI: https://doi.org/10.5962/bhl.part.24480

Permalink: https://www.biodiversitylibrary.org/partpdf/24480

\section{Holding Institution}

American Museum of Natural History Library

\section{Sponsored by}

Biodiversity Heritage Library

\section{Copyright \& Reuse}

Copyright Status: NOT_IN_COPYRIGHT

This document was created from content at the Biodiversity Heritage Library, the world's largest open access digital library for biodiversity literature and archives. Visit BHL at https://www.biodiversitylibrary.org. 